\title{
APPROACHES FOR QUALITY IN PEDAGOGICAL AND DESIGN FUNDAMENTALS IN MOOCS
}

\begin{abstract}
Connectivism and behaviorism are the main educational paradigms that describes the two most known types of MOOCs, named as cMOOCs and xMOOCs. Some aspects of pedagogical approximation in this type of courses are the mainstream of study and debate nowadays, such as quality and adequate approaching. In this reflection, it's shown some reflections about problematical pedagogy approaches to be solved and pedagogical and design approaches from various authors to bring quality to MOOCs.
\end{abstract}

Key words: MOOC; learning design; pedagogy; online learning; open educational resources; quality.

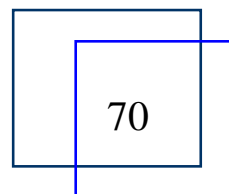




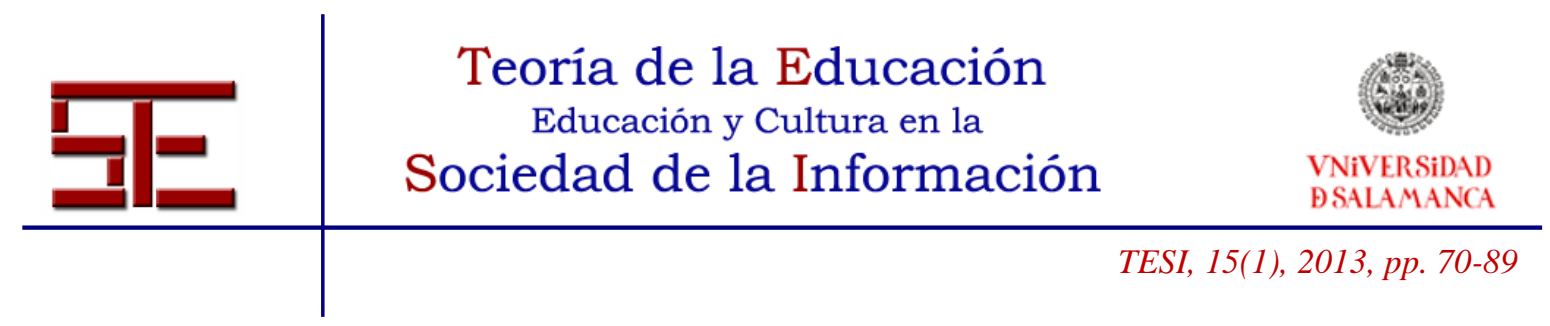

\section{ENFOQUES PARA LA CALIDAD EN LOS FUNDAMENTOS DE DISEÑO Y PEDAGÓGICOS EN LOS MOOCS}

Resumen: El conectivismo y el conductismo son los principales paradigmas educativos que describen los dos tipos de MOOCs más conocidos, nombrados como cMOOCs y xMOOCs. Algunos aspectos de la aproximación pedagógica en este tipo de cursos son en la actualidad la corriente principal de estudio y debate, tales como la calidad y aproximaciones adecuadas. En esta reflexión, se muestran algunas reflexiones acerca de los enfoques pedagógicos problemáticos que habría que resolver, y enfoques pedagógicos y de diseño de diversos autores para acercar la calidad a los MOOCs.

Palabras clave: MOOC; diseño de aprendizaje; pedagogía; aprendizaje en línea; recursos educativos abiertos; calidad.

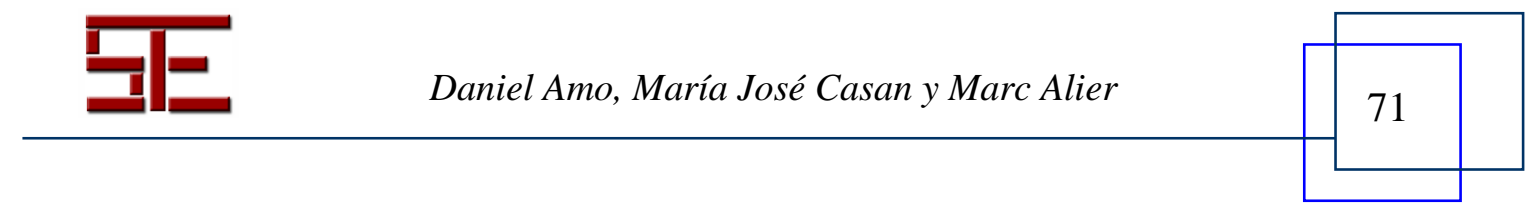




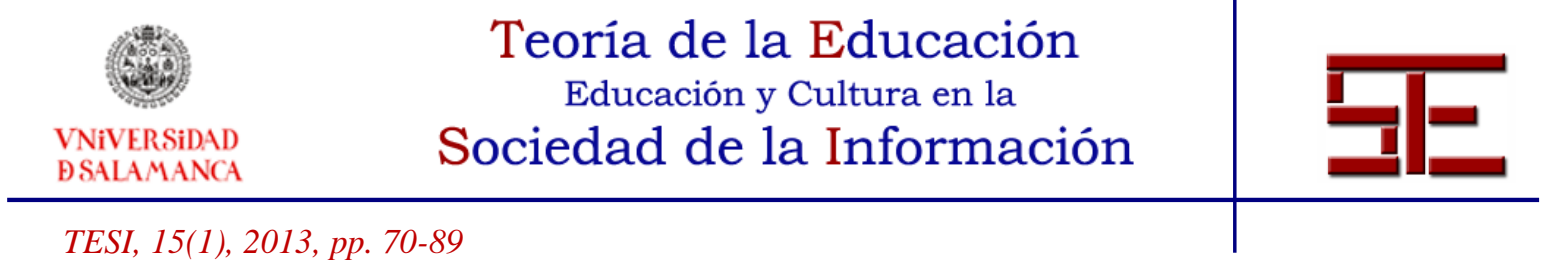

\section{APPROACHES FOR QUALITY IN PEDAGOGICAL AND DESIGN FUNDAMENTALS IN MOOCS}

Fecha de recepción: 20/010/2013; fecha de aceptación: 15/12/2013; fecha de publicación: 28/02/2014

Daniel Amo

damof@uoc.edu

María José Casany

mjcasany@essi.upc.edu

Universitat Politècnica de Catalunya

Marc Alier

marc.alier@upc.edu

Universitat Politècnica de Catalunya

\section{1.- INTRODUCTION}

There are compelling reasons to affirm that MOOCs have revolutionized the higher education in all of its aspects since the first cMOOC apparition by hand of Siemens and Downes (2008). Though MOOCs are in its initial experimental stage, these can't be considered as fad but an authentic disruption, justified by the advent of the last events that show how American Universities have rushed to offer this type of online courses, with accreditations and integrating them in its syllabus.

Notwithstanding the importance of these facts, of which has been much hype in the media and many research studies focused on, particularly to prognosticate the universities future and the next possible movements of the catalysts of MOOCs, is required identify and enhance which are its education pillars and which design and pedagogical approaches are necessary to offer an effective student centred learning of quality and adaptive.

The technology-based education enhances the learning process and facilitates learners' empowerment (Berlanga et al., 2010), among other remarkable qualities. Furthermore, this technological irruption almost obligates universities to adapt entirely its education and business models. The insight shift of the universities towards a 2.0 educational experience has its basis on several researches done around technology applied to education. These researches show beneficial outcomes in learning processes, but sometimes aren't spread in a suitable way. In this aspect, some authors as GarcíaPeñalvo et al. $(2012,2013)$ and Alier et al. (2012a) reflects on the need of spreading this knowledge in technology-based education. Also these authors shows new approaches to a 2.0 e-learning adoption for universities and how they should integrate

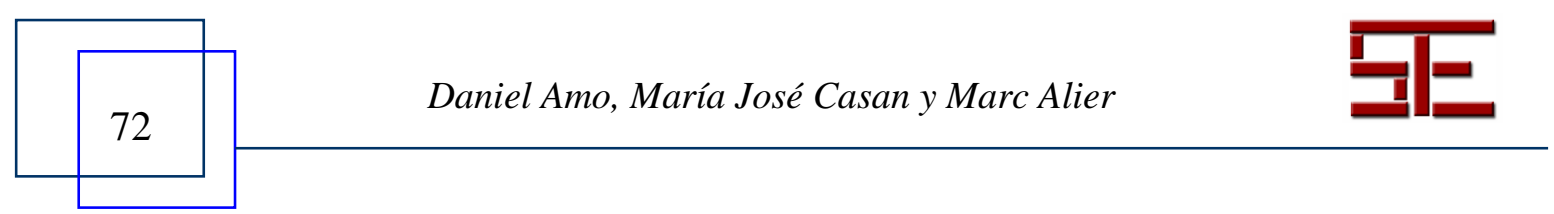




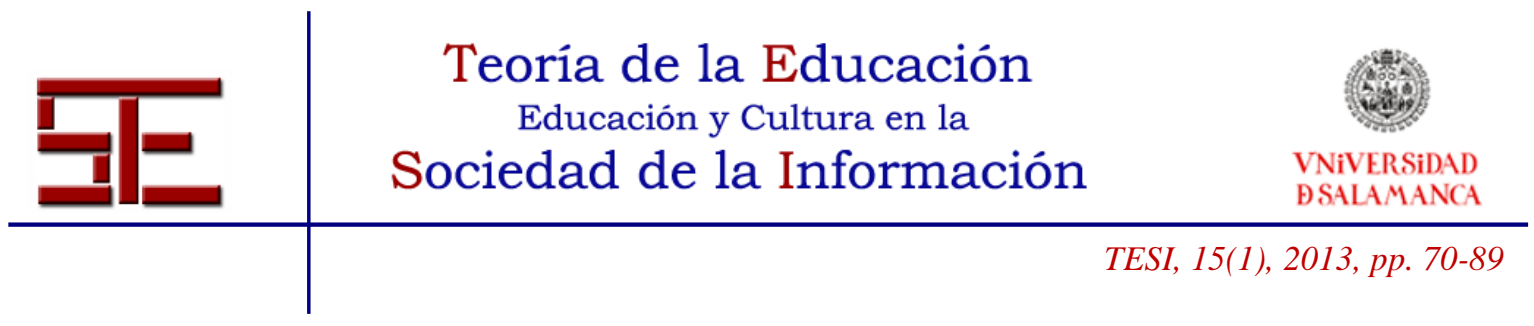

the Web 2.0 technologies an tools into its educational an institutional practices (Berlanga et al., 2010; Alier et al., 2012b). Considering these 2.0 insights, MOOCs are considered the result of the e-learning evolution since the technological irruption in the universities' educational context.

Hence, this paper aims to shift away the discussion about the future place of MOOCs in the universities context, its 2.0 technology-based education adoption and the ecology emerging companies in orbit around it, and centre the content in how to improve quality of them and offer an effective and adaptive learning to enrolled students. To this effect, is necessary introduce the actual situation of MOOCs, which motives are behind this learning disruption and the benefits that could offer to all the learning community as experimental entities to understand why is necessary to develop quality courses in design and pedagogy. After this and before explicating principles to enhance MOOCs quality in areas like web \& learning design, learner empowerment, peer assistance and assessment, gamification or learning analytics, some pedagogical and design fundamentals are presented in a reflection mode. Examples, initiatives and references for each area are shown also.

\section{2.- MOOCS AS DISRUPTIVE INNOVATION}

The actual situation of post-secondary education in United States of America is critical. American university students have been forced to acquire long-term debt due of the high cost of tuition and mandatory purchase of textbooks to access the contents of the subjects (Epelboin, 2013). This has caused a dramatically descent in the rate of students enrolled and therefore is forecast a lack of professionals in some sectors in the next decade. According to the Organisation for Economic Cooperation and Development 2012 Indicators report (OECD, 2012), only 42\% of young Americans ages 25-34 currently hold an associate degree or higher.

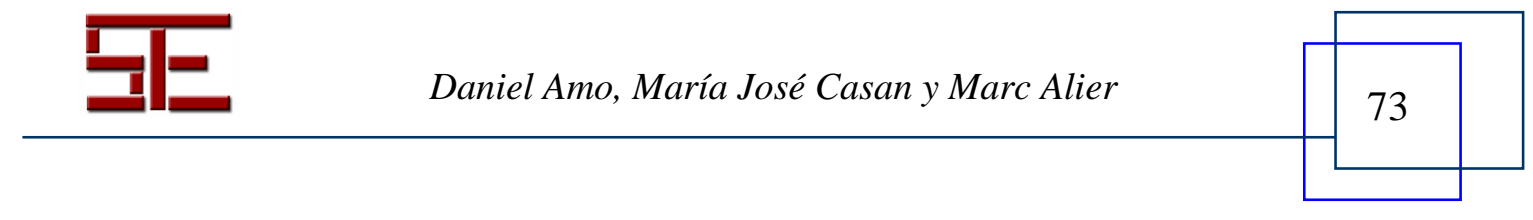



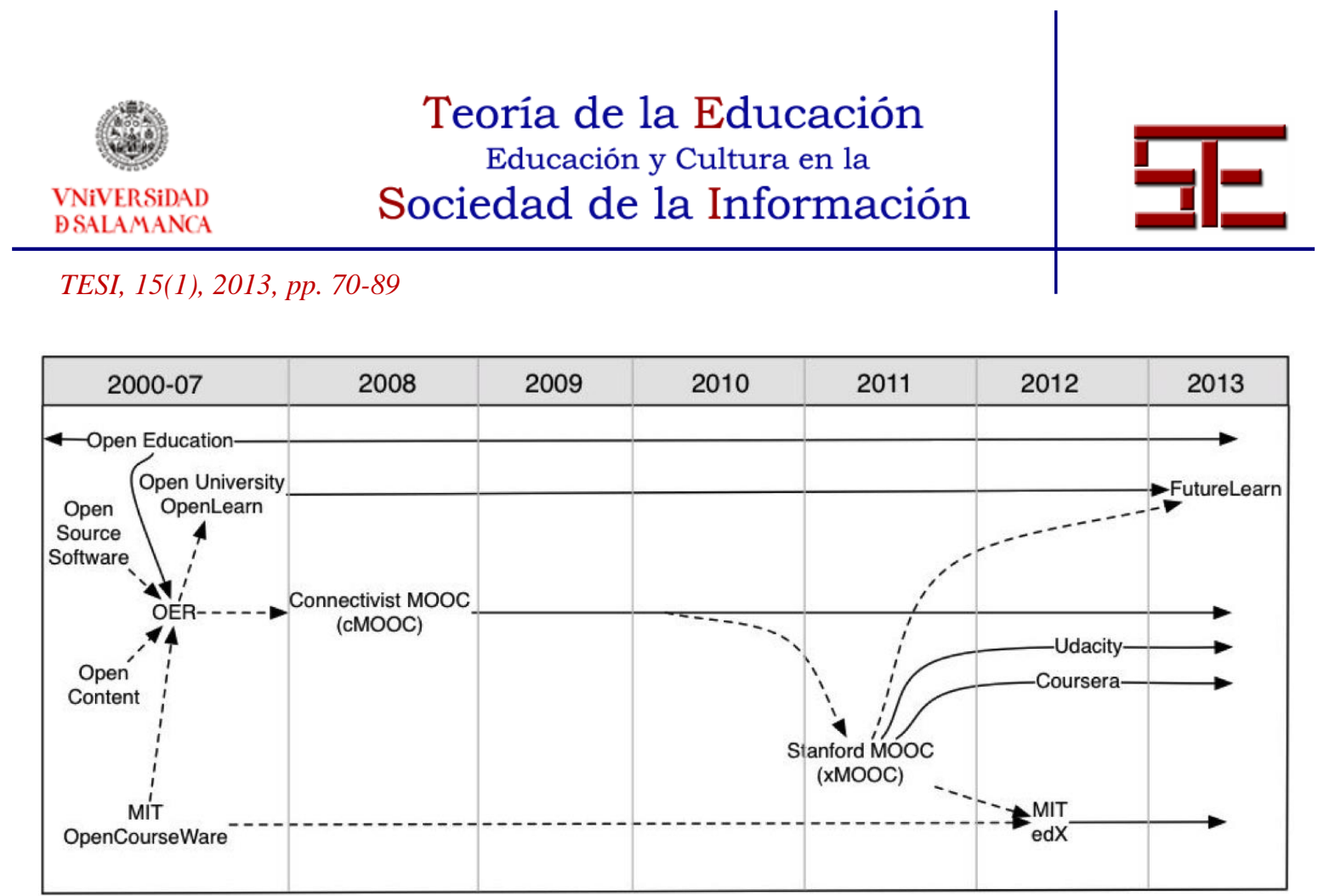

An influence

Directly related

Figure 1. MOOCs and Open Education Timeline (Yuan; Powell, 2013)

The apparition of cMOOCs propitiated by Siemens and Downes (2008) could be considered as the right extreme limit of the evolution of the open education, which have resulted in a rupture with the traditional educational system, even could make disappear in a mid term the brick-and-mortar institutions as how are actually known. Open education provides innovative opportunities in higher education where American universities have managed to adapt its current business model in a record time (see Figure 1) (Yuan; Powell, 2013), according to their own needs, such as escape routes to the crisis they are facing as mentioned by Epelboin (2013). The emerging MOOC type has been categorized as XMOOC and is based on a behavioral epistemology (Daniel, 2012).

Overall, considering the business context and Christensen "Disruptive Innovation" term (Christensen, 1997), MOOC are disruptive innovators due to allows a whole new population of consumers at the bottom of a market access to a product or service that was historically only accessible to consumers with a lot of money or a lot of skill. Universities's tuitions and hight-cost book classroom content business model are considered the expensive and inaccessible products, so MOOCs can break this situation and let universities to reorder the historical and traditional context they rendered until nowadays (Epelboin, 2013). Universities are also forced towards disaggregation of educational elements as faculty, curriculum and credentials as new business model due they cannot afford alone the change. Finally there is a compelling reason to believe that this MOOC disruption changes are affecting not only American universities, but to all

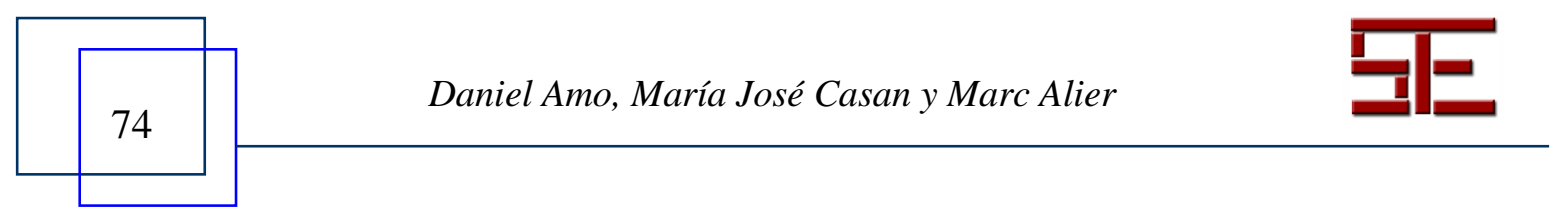




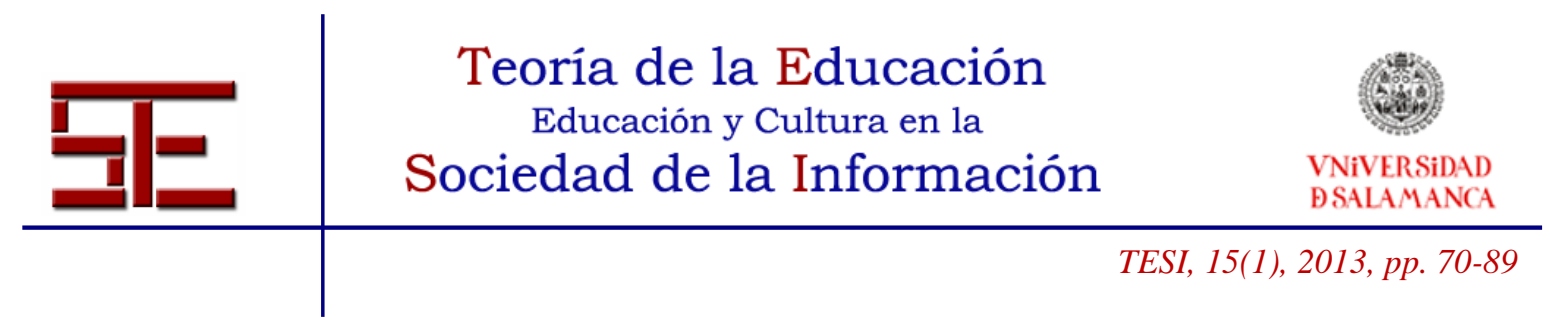

the other ones of other countries due to the rapid affluence and emergence of MOOCs platforms in those ones, like MiríadaX (Miríada X, 2013) or UNIMOOC-aemprende (UNIMOOC-aemprende, 2013). Notwithstanding this platforms irruption, further investigations have to be done in order to assure that there is a real accessibility to all the developing countries' population and not only a part of it, as exposed by Rekha et al. (2013). Concerning theses aspects, some author's approaches are needed to be cited concerning to this issue in order to state the awareness of the educational disruption around MOOCs. MOOCs are experimental entities and are needed of new approaches of educational innovation to be set as a definitive educational disruption for quality and effectiveness. Authors as Fidalgo et al. (2013a) reflect on this experimental issue and proposes a methodology for developing adaptive cMOOC. In the same way, Fidalgo et al. (2013b) propose a collaborative MOOC as integration between cMOOCs and xMOOCs.

\section{3.- QUALITY AS LEARNING EFFECTIVENESS AND SUSTAINABILITY BASIS FOR DEMOCRATIZATION OF CONTENT AND ACCESS}

MOOCs aren't only disruptive in the business context, but also in the learning one, e.g. causing 160.000 registered students in a course on artificial intelligence at University of Stanford (Osvaldo, 2012). Aggregating the massive quality to OOCs and moving the incampus network to the online and opened one the institutions can't replicate the same learning model and it's fundamentals face-to-face mode as Siemens (2012) stated. There are a lot of aspects of the MOOC to be explored and many research questions formulated, maybe the most important: Can MOOCs be used to improve student outcomes? Are MOOCs a good tool for learning? The answer maybe stands in a new technological approach reformulation of online learning tools to enhance the design and pedagogical fundamentals of MOOCs, in order to offer effectiveness and sustainability in this new learning model, like in the face-to-face one, as long as there is a quality basis as a through line.

\section{1.- Massiveness's benefits in democratized content and access}

Open education brings two paths of democratization, content and access. Universities take advantage of such democratization and add massive value to the courses, placing the MOOCs in the last stage of evolution of open educational resources (Mazoue, 2013). The opening of content is a benefit that allows students access to knowledge of high recognition professors universities like Stanford or Harvard. Moreover, open access allows students to enjoy a unique learning process, self-tests, activities and relationships in heterogeneous networking and rich in knowledge and experience. An example of this are the 132 MOOCs available on March 2013, 92 of them offered by Coursera and divided into various disciplines: Computer Science 61, 21 Business and Management, Humanities 14, 13 Science, 12 Health and Medicine, 8 Mathematics and Statistics and 3 Engineering (Rekha et al., 2013).

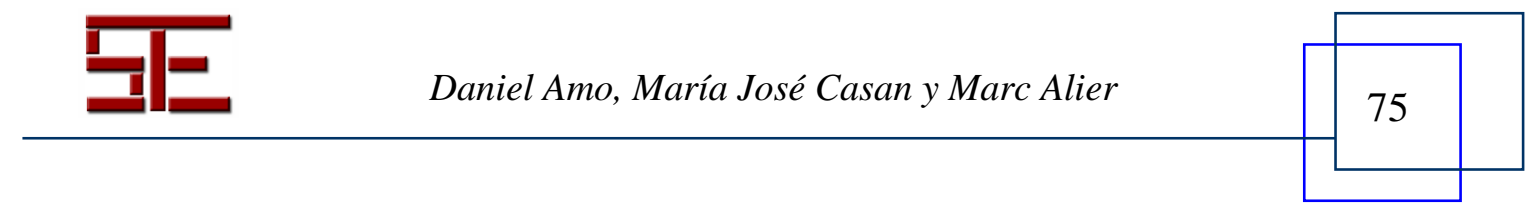




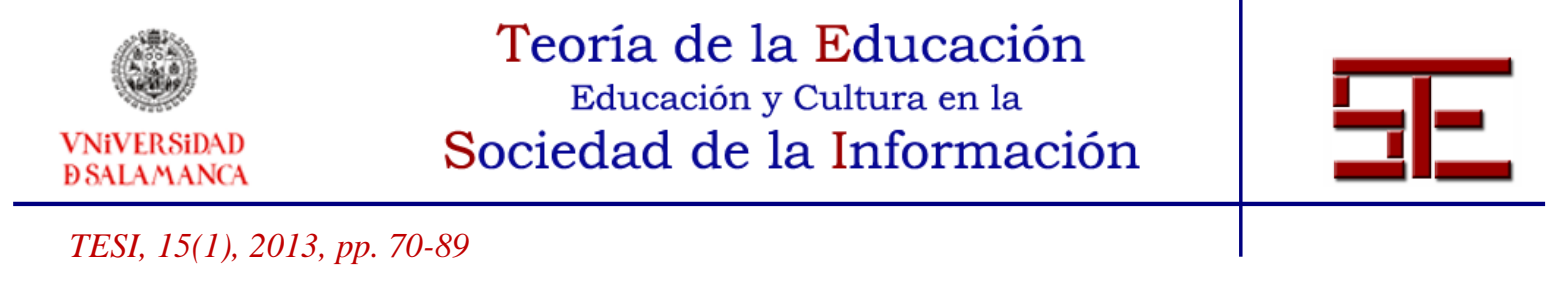

Finally, thanks to this value of massiveness it's possible to access a certification system at a very low cost in comparison to the high prices of the brick-and-mortar degrees, e.g. the online Master's Degree in Computer Science offered by Udacity, Georgia Tech, and AT\&T at a cost less than $\$ 7000$ (Watters, 2013). Considering traditional institutions, the same that are promoting the XMOOCs, certification would not be possible to all due to the excessive prices charged.

\section{2.- Quality basis}

Universities are aware of the benefits of democratization, but not everything is open content, access and encourages masses to enrolment. xMOOCs providers are aware that there is a third pillar, such as quality, which is critical to the massive success of itself and in that statement lies the MOOCs continuous experimentation.

Although improving the quality of student learning is one of the priorities of the major MOOC providers, most of their courses currently lack a sophisticated learning architecture that effectively adapts to the individual needs of each learner as mentioned by Mazoue (2013). The quality in the design and pedagogy of MOOCs are the based factor for the sustainability of enrolled student learning as well as their credibility and acceptance as a valid entity of learning. Experimentation is required and is where MOOCs itself could evolve into adaptive learning system as a direct benefit to the students in their learning process, and to universities in their new business model, thus providing absolute quality content and learning architecture.

Luckily authors like Sangrà and Guàrdia (2013), Mazoue (2013), de Waard (2013), George, Forsey and Riley (2013), Sonwalkar (2013) among many others, have dedicated their efforts to establish a fundamentals of design and pedagogy for MOOCs in order to meet a quality criteria to convert them to an adaptive and effective learning environments. Furthermore, there is a debate about the adequate pedagogy subjacent in MOOCs that could deliver problematic and inadequate courses to students, pedagogically talking, as some authors denote in its researches like Barberà (2013) and Mackness et al. (2013).

\section{4.- PEDAGOGICAL AND DESIGN FUNDAMENTALS}

In terms of principles of design and quality pedagogy in MOOCs appears some reflective proposals that permits different glimpses to supply into MOOCs ecology with significant courses to students, always oriented to a learner-centered (Sangrà et al., 2013) and personalized (Mazoue, 2013) learning.

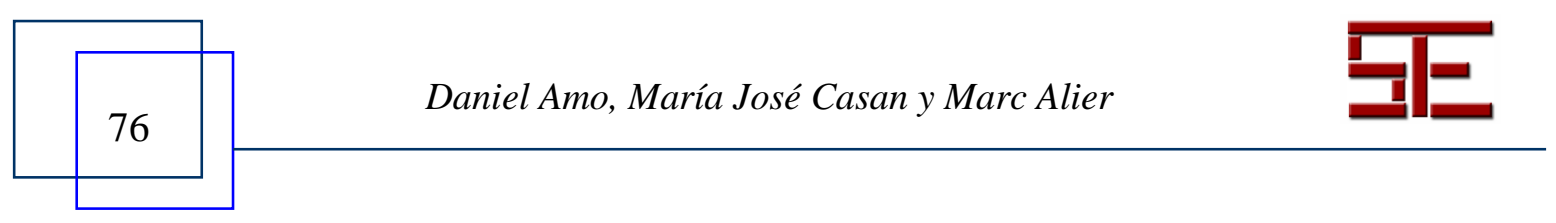




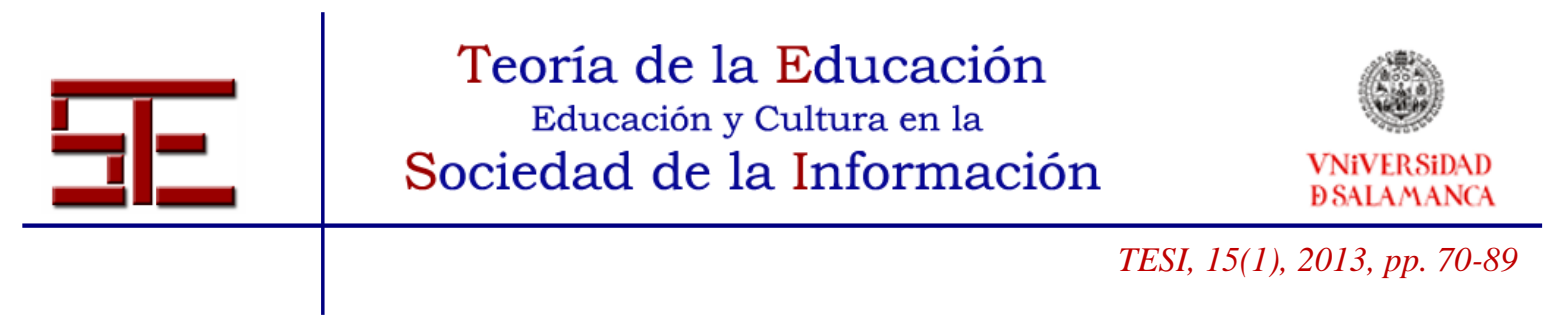

\section{1.- Precision-built MOOC}

The header of this section is named as such due the idea that the underlying technologies in MOOCs allow precision in the process of guiding students in their learning online (Mazoue, 2013). This accuracy depends heavily on continuous technological experimentation that determines the MOOCs as potential educational positioning systems.

Approaches to learning analytics system support such concept. As Mazoue (2013) remarks, these learning analytics used properly could result in a positive impact on student performance, for example, identifying areas where students are struggling and to send content and support and practical exercises to help them learn effectively.

Technological experimentation not only includes learning analytics as technological innovation to be considered in the design of MOOCs. Bloom (1968) focuses on two learning conditions such as tutoring one-on-one and mastery of learning as the most suitable for effective learning. Such conditions in an online space as MOOCs could be achieved with a well-defined technology strategy to let students interact with each other and supported by technological automation, because the teacher is not able to assess and provide meaningful feedback to all students due of the massive enrolment in courses, as Devlin (2012) reflects in his blog. Indeed, institutions cannot hire all the necessary human resources to conduct all assessments effectively. Therefore, a based technology solution is needed for building an assessment and tutoring systems automatable and intelligent to approximate such effectiveness and deliver a personalized student learning (Glance et al., 2013).

Such systems as automated marking provide instant feedback that can be combined with formative quizzes to enhance learning. Such approaches are being carried out as a pilot by some MOOC providers to offer ASAP tutoring and assessment systems automatable, intelligent and effective. Edx, MIT and Harvard's non-profit organization, has announced that it will use Automated Essay Scoring (AES) (Balfour, 2013) for assessing writing in its MOOCs, specially one that have been tested and established in the academic literature. On the other hand, Coursera have decided to use, as they call it, "calibrated peer review" evaluation to assess writing, method of peer review distinct form an application developed by UCLA with National Science Foundation funding called Calibrated Peer Review ${ }^{\mathrm{TM}}$ (CPR) (2012). Notwithstanding the experimentation stage and new application method approaches for automated assessment, recent experiments reports reveal a high degree of acceptance of these assessments methods as mentioned by Sandeen (2013).

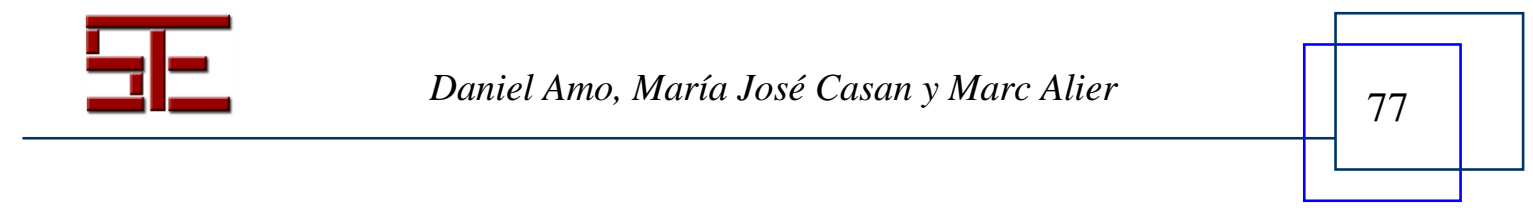




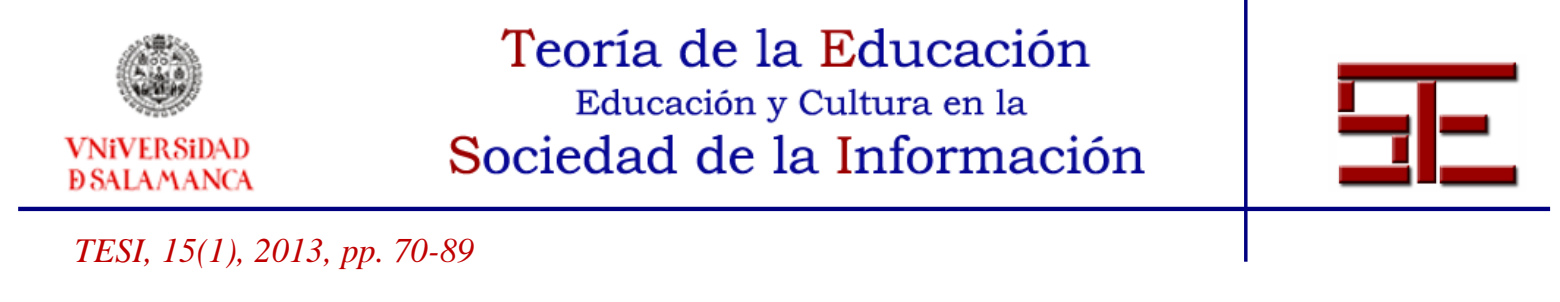

\section{2.- Team course development}

New emerging initiatives in MOOC format such as OLDS-MOOC (McAndrew, 2013) proposes clear MOOCs design approaches including creating MOOCs from an interdisciplinary team of professionals. Beyond this, these types of initiatives in experimental situations basis permits to analyse themselves how to improve exposed principles in the course and draw conclusions from the reports made from the experiences of the design team, implementation, faculty and students. The conclusions drawn indicate necessary experimental and new prototyping iterations of the MOOC to solve problems arisen and improve instructional design in technology basis.

Another strong bet from McCallum et al. (2013) for developing MOOCs from heterogeneous teams is AlphaMOOC, which support the premises defined in OLDSMOOC (McAndrew, 2013). They use the term aMOOC to represent this type of courses developed by multiple intelligences as a team that uniquely combines all cMOOCs and xMOOCs essentials. This aMOOC proposal lies in the concept of learning while developing and experimenting, where all teams interact and learn along the course creation process. McCallum et al. further propose a structure of teams such as curriculum, educational technology, accessibility and diversity, social media and evaluation, which brings better qualitative results in comparison with those MOOC developed only by one person.

Finally, the authors behind aMOOCs have pointed that this type of resulting courses built by heterogeneous professionals enriches the development process and allows to create a learning community within the team itself, which indeed it could be reflected in a quality result, thus avoiding loneliness to those teachers who develop MOOCs autonomously.

\section{3.- $x$ MOOCs should be cMOOCs}

Moya (2013) reflects on what kind of MOOCs should prevail in online education. Based on the Delors's defined pillars to ensure education (Delors, 1996), such as learning to know, learning to do, learning to live together and learning to be, the author concludes that $\mathrm{cMOOCs}$ are the ones that integrate those pillars and therefore are more valid to promote Educational Renewal Movement inspired by M. Montessori, C. Freinet, Ferrer i Guardia, where experimentation and discovery become an aspect that leads to new knowledge and experiences. Moya proposes to use the cMOOCs as a proposal with great scope, so training and education could be ensured at the level of adult education, and thus enhances the sense of long life learning linked to learning by doing from the network and its possibilities offered.

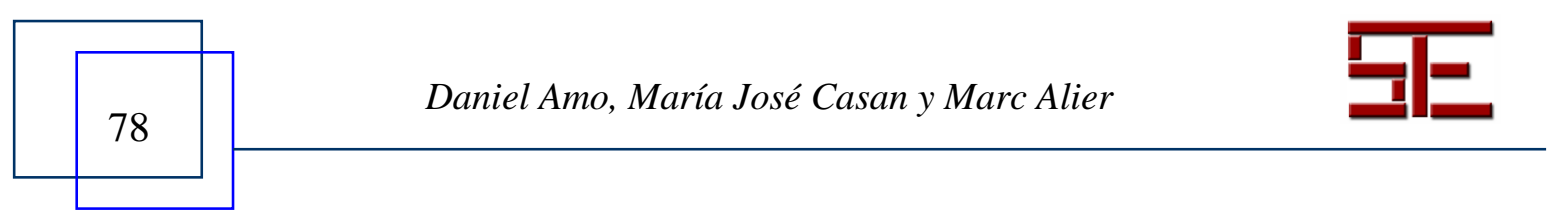




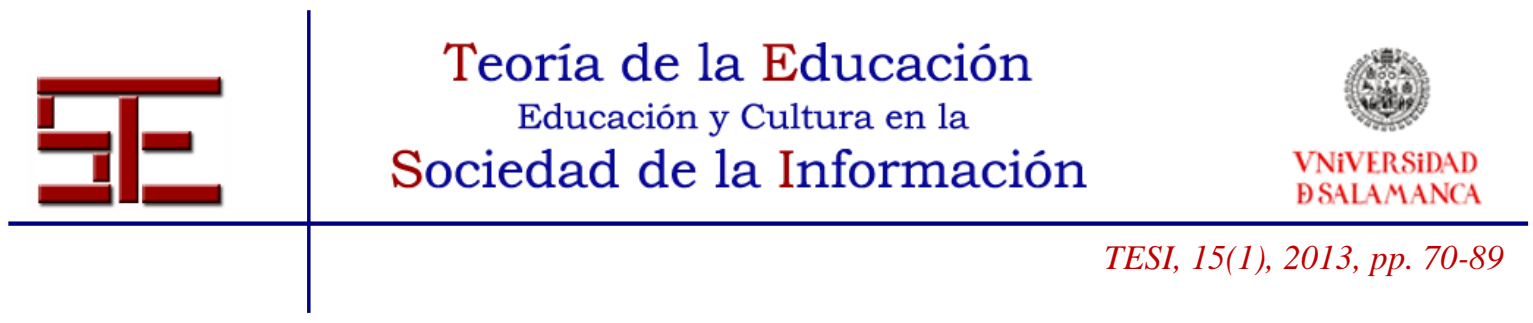

Still, such reflection could be modified soon due the great experimental continuous iteration that are suffering the MOOCs in their design bases, and so balance in a short term the bascule that the four Delors' pillars are inclining to cMOOCs as ideal long life learning courses.

\section{4.- Problematical approaches}

Some researchers denote problematic approaches in both types of MOOCs that could deliver inadequate courses to enrolled students. The reflection about the following aspects is necessary in order to deliver quality pedagogy practices and adequate design approaches.

\subsection{1.- xMOOCs are flat}

Clark (2013) reflects in its paper that the structure and course flow of xMOOCs is generally equal, with very little difference between them. The author continues arguing that most of the xMOOCs are linear and sequential oriented courses based on video under demand plus a questionnaire associated to and some peer-to-peer evaluation assessments. This course flow denotes a flat model that forks each student to a unique learning path, unadapted learning and potentially dropout rate.

Clark (2013) indicates a possible solution in an adaptive learning design approach that could empower the learner and reduce the high MOOCs dropout rates and the flatten of the actual "YouTube plus question" feeling, as the author mentions literally.

\subsection{2.- cMOOCs as inadequate and problematic learning}

Barberà (2013) reflects on the aim of cMOOCs about explaining learning as it happens in web 2.0. Barberà $(2013,130)$ argues "that connectivism is not able to adequately explain how learning occurs, neither in Web 2.0 nor in any other environment because it does not address many of the central attributes of learning". In such reflection are defined three important explanatory problems of the connectivist theoretical assumptions:

-Connectivism does not address at all what is known as the "learning paradox.", first posed by Socrates (Plato, 2002).

-Connectivism underconceptualizes interaction and dialogue, by understanding it as a learner's connection to a human node in the network.

- Connectivism is unable to explain concept development.

The author concludes that "connectivism does not provide an adequate explanation of learning phenomena in Web 2.0, and therefore it is not able to provide an adequate pedagogy for MOOCs" (Barberà, 2013, 131).

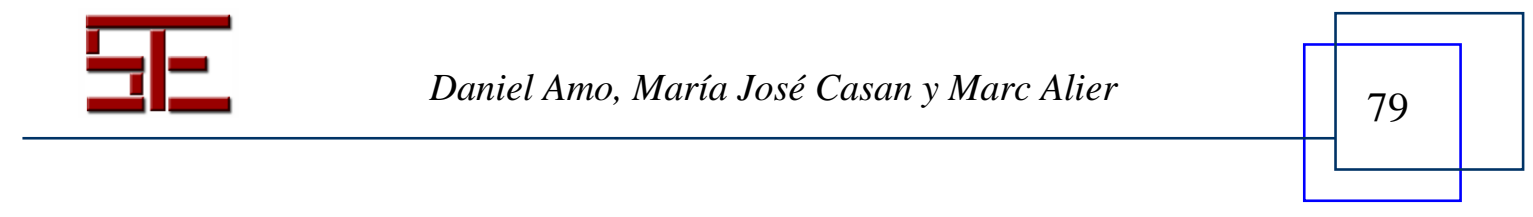




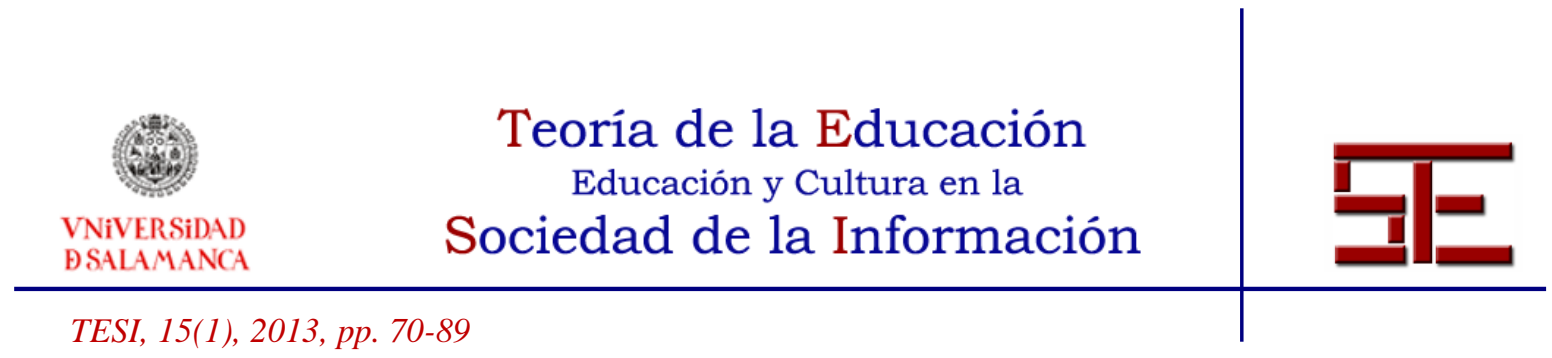

\section{5.- EXPLICIT PRINCIPLES FROM RESEARCHERS TO ENHANCE MOOCS QUALITY}

\section{1.- Responsive web design}

This paper is focused on which fundamentals of design and pedagogical approaches exists or are proposed by different researchers to provide quality to MOOCs, so showing some ideas about interface design is not the main focus. Anyway, have to be said that there is a clear movement to enhance the access in order to make MOOCs web platforms compatible with existing multiple devices, such as proposals by Sánchez and Escribano (2013), and avoid the hype cycle model formulated by Gartner (2012) (see figure 2).

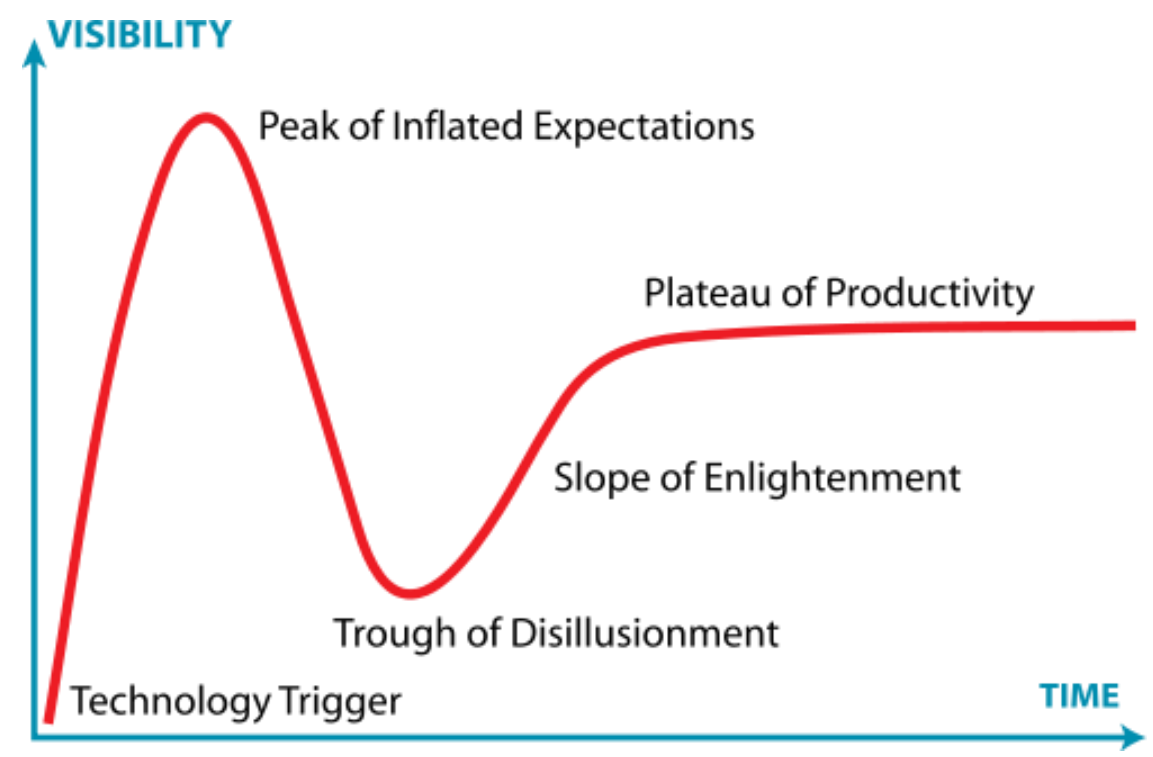

Figure 2. Hype Cycle (Gartner, 2012)

\section{2.- Learning design}

Some authors are conscious that there is a lack of pedagogical approaches in the technological platforms and instructional design running in nowadays MOOCs (Sangrà et al., 2013). Transferring the traditional face-to-face model to MOOCs new model has generated some common sense technological approaches like automated quizzes and marking. Therefore, some pedagogical approaches have to be proposed for MOOCs quality design and effective adaptive learning. This situation denotes that the MOOCs are still in their initial stage of experimentation and is needed some more course iterations.

Some of the pedagogical approaches are shown in these sections to provide some fundamentals to quality MOOCs development for effective and adaptive learning.

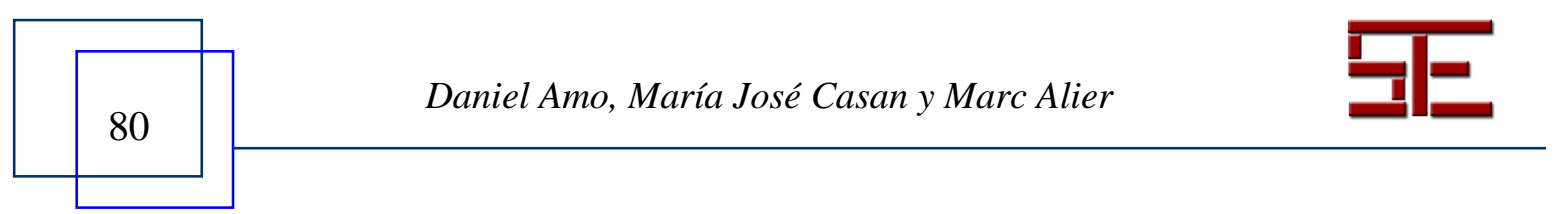




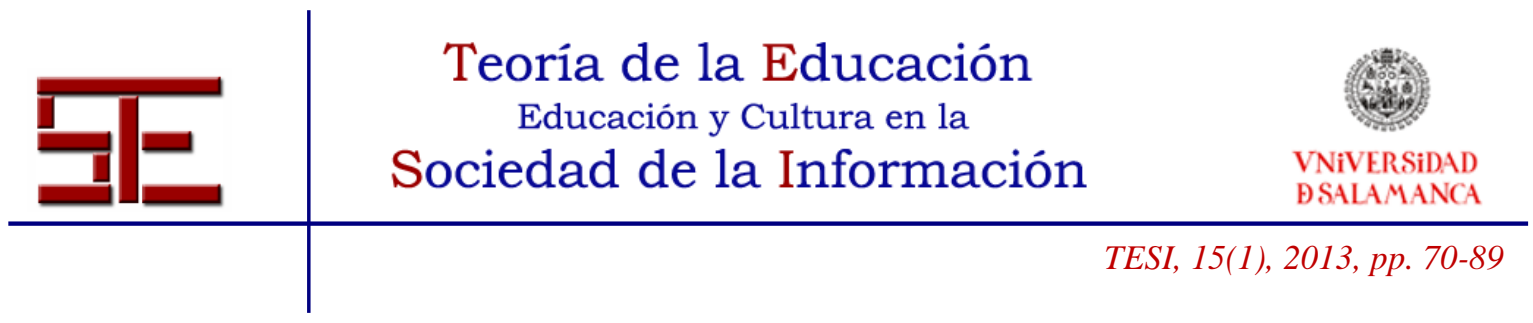

\subsection{1.- Learner empowerment}

MOOCs should deliver an adaptive learning to permit students leverage its own learning process. In order to accomplish this, MOOCs have to show a clear learning plan and orientations, well-developed schedule with tasks, assignments and deadlines as providing a pace for learning as mentioned by Sangrà et al. (2013). As they say, foster peer-to-peer collaboration, assistance, self-paced and self-directed learning in all of its aspects loads the students with a self-confidence feeling that promote its empowerment and engagement. In this aspect, MOOCs have to foster self-assessment, that is said to facilitate greater autonomy in learning and an effective manner to develop self-learning skills required for achievement in an online learning environment, idea that coincides with George et al. (2013).

This idea of learner empowerment is directly associated with the adaptive learning one. Authors like Clark (2013) believe that adaptive learning is a possible approach to reduce the high dropout rates that are experimenting MOOCs. Concerning this aspect, some authors like Sonwalkar (2013) conducted an original research to test a pedagogical framework that offers a 5 different learning path course, which they called aMOOC or adaptive MOOC.

Initiatives like Grünewald et al. (2013) one propose an evolution of the XMOOC by developing tools that allow users to create diverging paths through the learning material, involve the user personally in the problem domain with (group) hands-on exercises and reward user contributions by means of gamification. In the other type of MOOC, authors as Fidalgo et al. (2013a) are aware of the benefits of an adaptive learning and proposes a methodology for developing adaptive cMOOC.

\subsection{2.- Competence-based}

As Sangrà et al. (2013) have pointed, this type of learning moves education from focusing on what academics believe graduates need to know (teacher-focused) to what students need to know and be able to do in varying and complex situations (student and/or workplace focused) (Sangrà et al., 2013). This approach necessitates more complex assessment, involving portfolios, experiential learning assessment in field experience, demonstration in varying contexts, role play, situation learning, etc..

\subsection{3.- Peer: assistance and assessment}

Massiveness is an added value to online learning due its social benefits, as Blom et al. (2013) have pointed in their research. MOOCs should foster peer assistance, selfassessment and automated and effective tutoring and assessment systems, such as AES and CPR, as is mentioned before to empower students' learning (Sangrà et al., 2013). A social approach for peer-to-peer learning (Purser et al., 2013) and peer howto guidelines to foster peer assistance could be two valid strategies in order to generate social

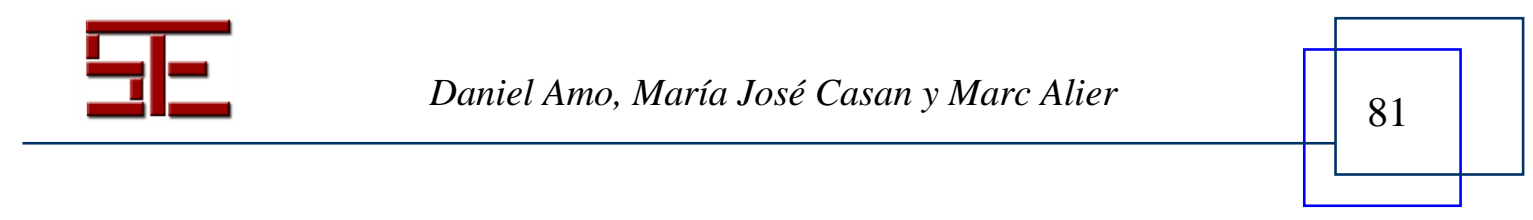




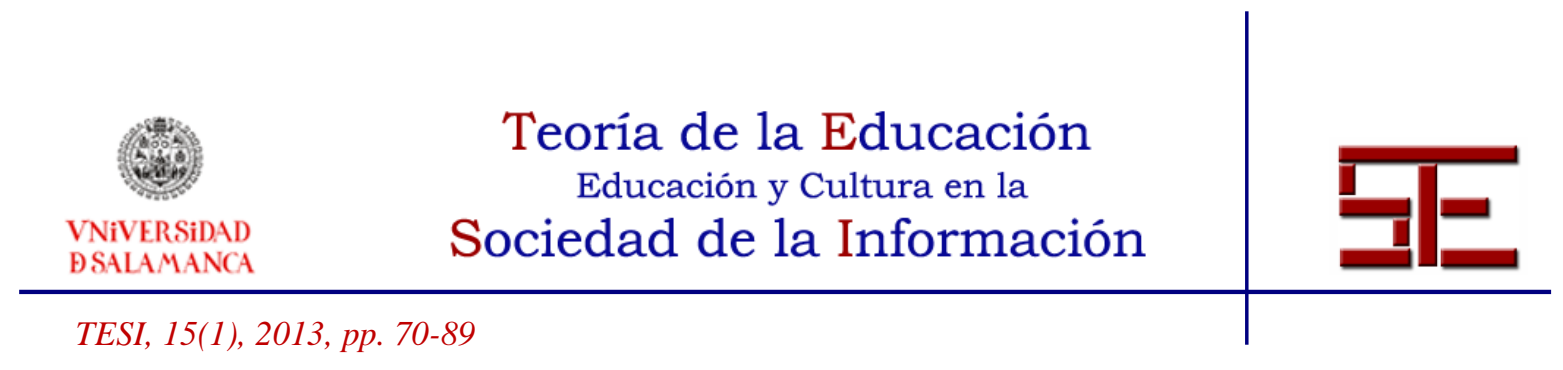

communities and a collective intelligence (Wikipedia, 2013) to reinforce knowledge and learning. One way of peer-to-peer learning in higher education is the concept of quadblogging (Towndrow et al., 2013) with its subjacent potential for facilitating and enhancing this type of interactive learning.

\subsection{4.- Social networking}

Aimed to boost collaborative learning and community groups to create learning opportunities and participate in a collective intelligence that is able to share knowledge in each peer-to-peer interaction, such as online forums and video discussions (Glance $e t$ al., 2013). Blom et al. (2013) say that MOOCs are neither social nor individual, but both, therefore some students will prefer to work alone and others will take advantage of team learning. In the last mentioned aspect, social qualities are the source of group forming and the establishment of durable peer cooperation. Therefore, a guidance to help learners create their own personal learning environment can keep a permanent connection with the network (Sangrà et al., 2013).

\subsection{5.- Quality media for all}

The importance of producing rich and quality media learning support may be crucial for both teachers and students. The first one should attempt to give students rich quality media to enforce its learning such as short format videos, as pointed by George et al. (2013). In this aspect de Waard (2013) adds that principles in content design have to be considered to provide interactivity, immediate feedback, small size content to fit contemporary lifelong learning and use information sources that are both recent, as well as those proven over time, always keeping access to content as simple as possible.

The second ones are required to be delivered a howto, rubrics or guidelines so they could generate rich quality content that will enhance its learning and peer learning. As Sangrà et al. (2013) remark in their design principles approach that rubrics, in conjunction with other learning guidance tools, give clues in how to collect learning evidence and organize them to provide accountability of learning trajectories.

\subsection{6.- Gamification}

The use of Digital Game Based Learning (GBL) (Van Eck, 2006) and Serious Games (SG) (Wikipedia, 2013) approach in the MOOCs could help to overcome the lecturebased approaches adopted in the main MOOC platforms as mentioned by Romero (2013). Romero remarks in relation with competence based learning that the use of GBL and SG could promote the development of more practical and applied competencies and knowledge.

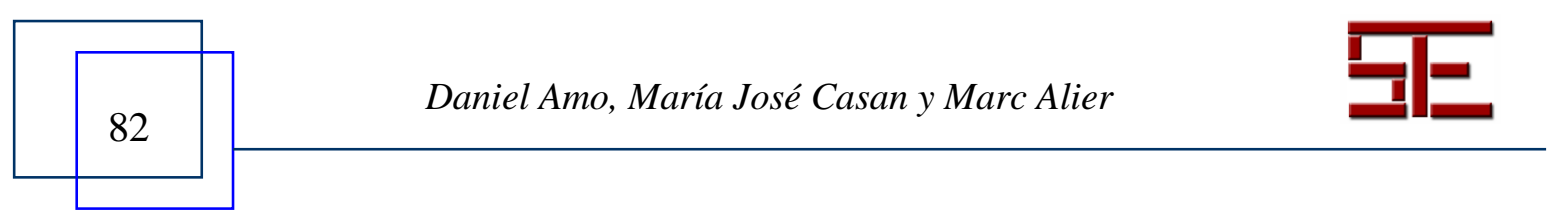




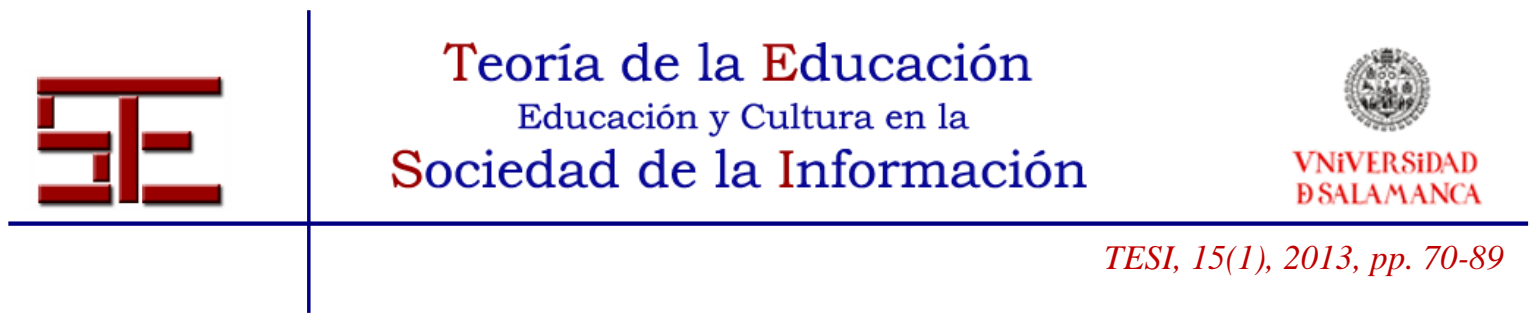

5.2.7.- Learning analytics, educational data mining and social network analysis

As Siemens et al. (2013) describes, "learning analytics is the measurement, collection, analysis and reporting of data about learners and their contexts, for purposes of understanding and optimizing learning and the environment in which it occurs". In the other hand, as Romero et al. (2011, XI) describes, "the primary goal of educational data mining is to use large-scale educational data sets to better understand learning and provide information about the learning process".

Using this both methodologies the MOOC team could give answer to the following questions and possibly redress the situation to avoid dropout, low outcomes and offer an adaptive learning environment (Romero et al., 2011; Baker \& Siemens, 2013; Clark, 2013):

- How different students choose to use different learning resources and obtain different outcomes?

-Does the class understand the material well enough to go on?

-Do any students require remedial instruction?

-Which students are likely to need academic counselling to complete school successfully?

In such methodologies Tabaa and Medouri (2013) base its research to generate a learning analytics system for MOOCs, called LASyM. Concerning the high dropout in MOOCs, these authors developed a method to identify online learners more likely to drop out. The use of learning analytics is leveraged to help them investigate massive raw data, generated by MOOC platforms around learning outcomes and assessments, and reveal any useful information to be used in designing learning-optimized MOOCs.

Kizilcec et al. (2013) also uses learning analytics to identify a small number of canonical ways in which students interact with MOOCs. In their research is presented a classification method to allow MOOC designers to develop adaptive course to learners.

Social network analysis is supported by learning analytics (Drljević, 2013) and is used to deliver significant predictors of dropout in MOOCs (Yang et al., 2013). Yang et al. (2013) presents in their research predictors that can avoid the high dropout rate concerning MOOCs that can be used by MOOCs suppliers to deliver quality courses and adaptative learning.

\section{6.- CONCLUSIONS}

In conclusion, the experimentation in MOOCs is the basis of its own evolution. Such experimentation provides benefits not only for students, which could improve their learning and outcomes, but also to the development team.

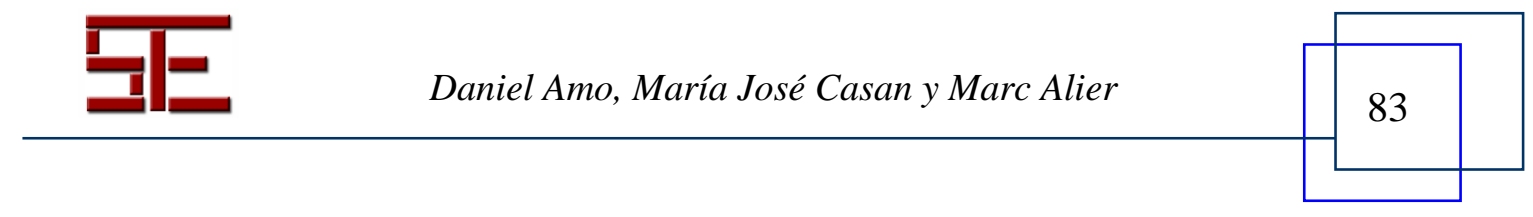




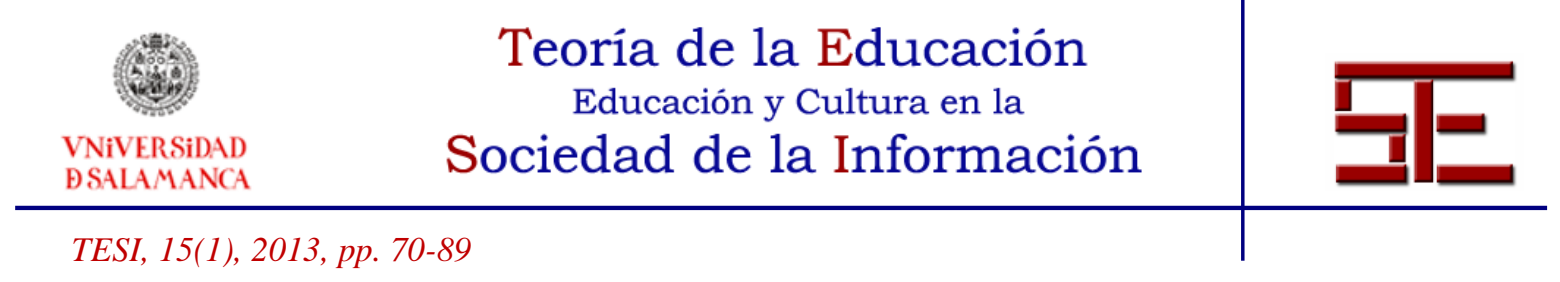

The main focus of developers of MOOCs is to create high quality courses, both in pedagogy and design fundamentals and media. Unfortunately there is no consensus about which of the actual design and pedagogical approaches are the most efficient to improve student learning outcomes, however there is an aware of the need for a quality delivery. Therefore, this shows how every MOOC approach is absolutely different from each other and indeed is needed more experimental iterations to consider MOOCs as consolidated learning environments and not as experimental situations.

Finally, this reflection shows some pedagogical and design approaches to bring quality to MOOCs that expect to be useful in someway. Possible problems associated to the epistemologies subjacent in the different types of MOOC are also shown and could be the cause of it's inadequateness, so some approaches have to be applied to avoid them. Such approaches as Learning Analytics and Educational Data Mining could be a possible solution, but not unique. Nonetheless, further researches have to be done to establish more accurate and validated principles and technological tools as basis of instructional design in order to convert MOOCs into effective and adaptive learning environments.

\section{7.- REFERENCES}

Alier Forment, M., Galanis, N., Casañ, Mª J., Mayol, E., Piguillem Poch, J., García Peñalvo, F. J., \& Conde, M. Á. (2012a). Didactical Patterns for the Usage of Wikis in Educational and Learning Activities. International Journal of Engineering Education (IJEE), 28 (6), 1347-1352.

Alier, M., Mayol, E., Casañ, M. J., Piguillem, J., Merriman, J. W., Conde, M. Á., García-Peñalvo, F. J., Tebben, W., \& Severance, C. (2012b). Clustering Projects for eLearning Interoperability. Journal of Universal Computer Science, 18 (1), 106-122. DOI: 10.3217/jucs-017-01-0106.

Balfour, S. (2013). Assessing Writing in MOOCs: Automated Essay Scoring and Calibrated Peer Review ${ }^{\mathrm{TM}}$. RPA, 8, Summer 2013, 40-48.

Berlanga, A. J., García Peñalvo, F. J., \& Sloep, P. B. (2010). Towards eLearning 2.0 University. Interactive Learning Environments, $18 \quad$ (3), 199-201. DOI:10.1080/10494820.2010.500498.

Bloom, B. (1968). Learning for Mastery. Center for the Study of Evaluation of Instructional Programs. California, CA.

Blom, J., Verma, H., Li, N., Skevi, A. \& Dillenbourg, P. (2013). MOOCs are More Social than You Believe. J. eLearning Papers, 33.

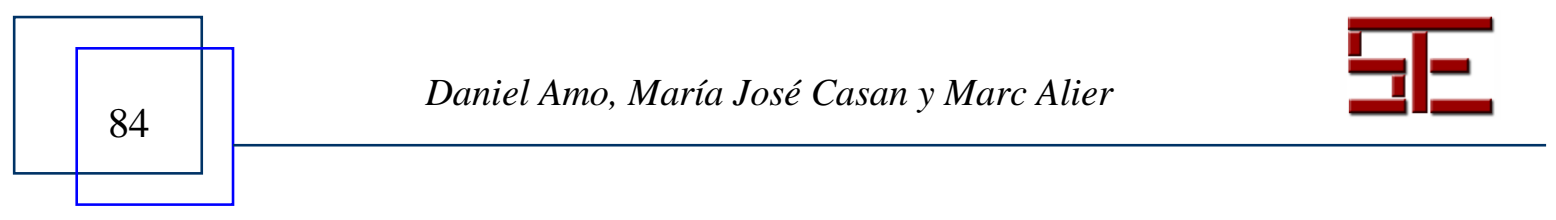




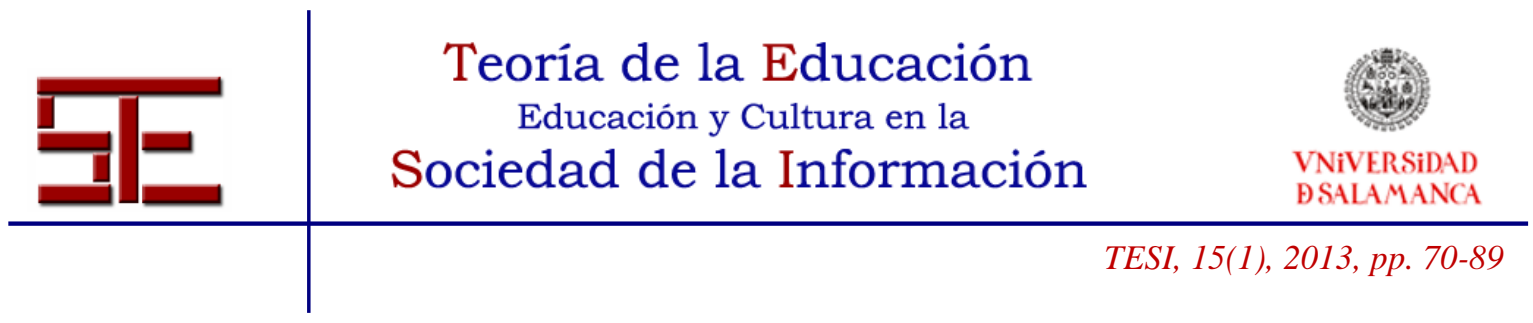

Calibrated Peer Review ${ }^{\mathrm{TM}}$ (2012). Web-based writing and peer review. Retrieved August 23, 2013 from http://cpr.molsci.ucla.edu/Home.aspx.

Christensen, C. (1997). Disruptive Innovation. Retrieved August 21, 2013 from http://www.claytonchristensen.com/key-concepts/.

Clarà, M. \& Barberà, E. (2013). Learning online: massive open online courses (MOOCs), connectivism, and cultural psychology. Distance Education, 129-136. http://dx.doi.org/10.1080/01587919.2013.770428.

Clark, D. (2013). Adaptive MOOCs. Retrieved November 21, 2013 from http://colearnrmedia.s3.amazonaws.com/education/moocs/adaptiveMOOC.pdf.

Daniel, S. J. (2012). Making Sense of MOOCs: Musings in a Maze of Myth, Paradox and Possibility. JIME.

Delors, J. (1996). The four pillars of education. In The Tresaure Within. Report to UNESCO of the International Commission on Education for the Twenty-first Century, 85-97.

Devlin, K. (2012). MOOC Lessons. Retrieved August 23, 2013 from http://devlinsangle.blogspot.com.es/2012/11/mooc-lessons.html.

Drljević, N. (2013). Learning and social network analytics in online learning systems. Master's Thesis No. 556. Faculty of Electrical Engineering and Computing, University of Zagreb.

Epelboin, Y. (2013). MOOC: a revolution in teaching? A European view. In 19th European University Information Systems Congress "ICT Role for Next Generation Universities”. EUNIS 2013. DOI:http://dx.doi.org/10.7250/eunis.2013.003.

Fidalgo Blanco, Á., García-Peñalvo, F. J. \& Sein-Echaluce, M ${ }^{a}$ L. (2013a). A methodology proposal for developing adaptive cMOOC. In F. J. García-Peñalvo (Ed.), Proceedings of the First International Conference on Technological Ecosystem for Enhancing Multiculturality (TEEM'13) (Salamanca, Spain, november 14-15, 2013). (pp. 553-558). Grupo GRIAL / ACM International Conference Proceeding Series (ICPS). New York, NY, USA: ACM. DOI: http://dx.doi.org/10.1145/2536536.2536621.

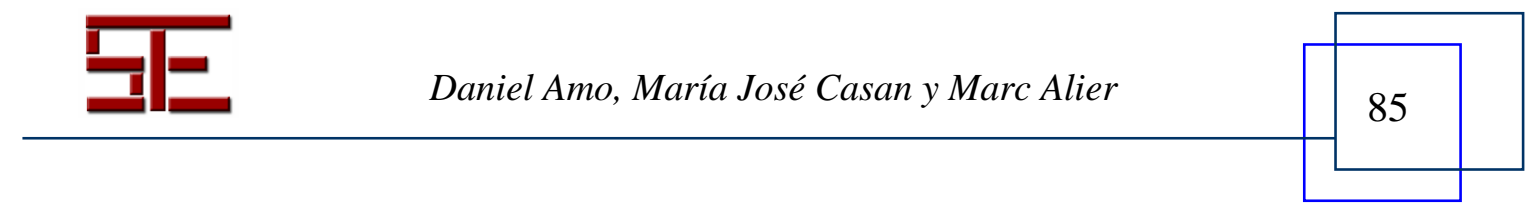




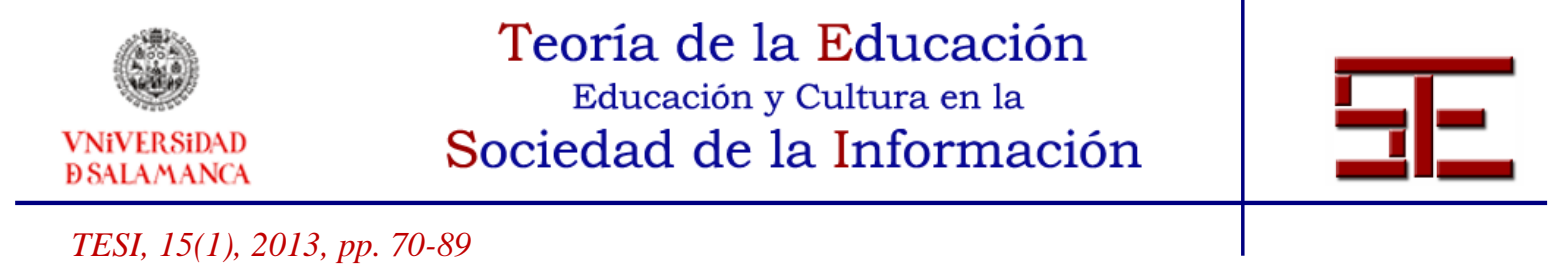

Fidalgo Blanco, Á., Sein-Echaluce, Mª L. \& García-Peñalvo, F. J. (2013b). MOOC cooperativo. Una integración entre cMOOC y xMOOC. En Á. Fidalgo Blanco, Ma L. Sein-Echaluce Lacleta (Eds.), Actas del II Congreso Internacional sobre Aprendizaje, Innovación y Competitividad, CINAIC 2013 (Madrid, 6-8 de noviembre de 2013). (pp. 481-486). Madrid, España: Fundación General de la Universidad Politécnica de Madrid.

García-Peñalvo, F. J., Colomo-Palacios, R., \& Lytras, M. (2012). Outcomes of International Research Projects on Technology Applied to Education. Journal of Universal Computer Science. 18 (1), 1-4.

García-Peñalvo, F. J., Velázquez-Iturbide, J. Á., \& Llamas-Nistal, M. International Research Projects on Socio-Semantic Technologies Applied to Education. Journal of Universal Computer Science. 19 (11), 1496-1499.

Glance, D., Forsey, M. \& Riley, M. (2013). The pedagogical foundations of massive open online courses. First Monday 18. DOI:http://dx.doi.org/10.5210/fm.v18i5.4350.

Kizilcec, R., Piech, C. \& Schneider, E. (2013). Deconstructing disengagement: analyzing learner subpopulations in massive open online courses. LAK '13 Proceedings of the Third International Conference on Learning Analytics and Knowledge (pp. 170179). http://dx.doi.org/10.1145/2460296.2460330.

Mackness, J., Waite, M. Roberts, G. \& Lovegrove, E. (2013). Learning in a small, taskoriented, connectivist MOOC: Pedagogical issues and implications for higher education. The International Review of Research in Open and Distance Learning. 14 (4).

Mazoue, J. (2013). The MOOC Model: Challenging Traditional Education. Retrieved August 23, 2013 from http://www.educause.edu/ero/article/mooc-model-challengingtraditional-education.

McAndrew, P. (2013). Learning from Open Design: Running a Learning Design MOOC. J. eLearning Papers, 33.

McCallum, C., Thomas, S. \& Libarkin, J. (2013). The AlphaMOOC: Building a Massive Open Online Course One Graduate Student at a Time. J. eLearning Papers 33.

Miríada, X. (2013). Bienvenid@ a Miríada X. Retrieved August 21, 2013 from https://www.miriadax.net/blog/-/blogs/bienvenid-a-miriada-X.

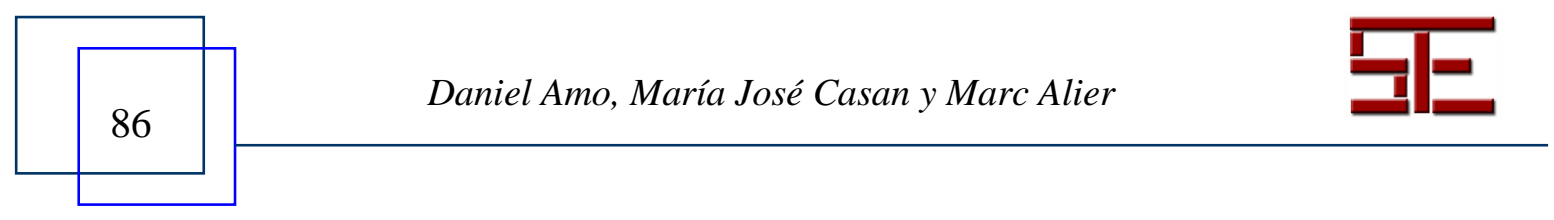




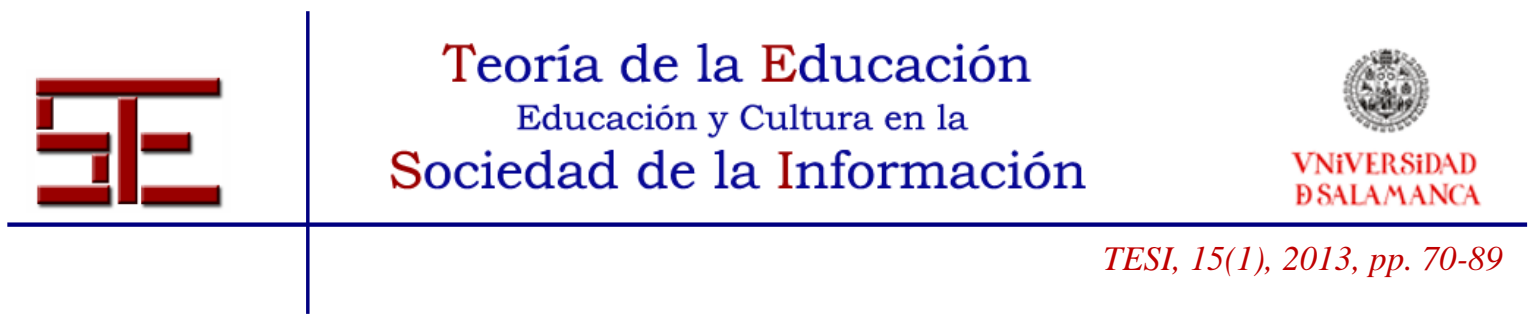

Moya, M. (2013). La Educación encierra un tesoro: ¿Los MOOCs/COMA integran los Pilares de la Educación en su modelo de aprendizaje on-line? SCOPEO INFORME, MOOC: Estado de la situación actual, posibilidades, retos y futuro, 2, 40-48.

OECD (2012). Education at a Glance 2012: OECD Indicators. OECD Publishing. DOI: http://dx.doi.org/10.1787/eag-2012-en.

Osvaldo, C. (2012). MOOCs and the AI-Stanford like Courses: Two Successful and Distinct Course Formats for Massive Open Online Courses. European Journal of Open, Distance and E-Learning, 2.

Purser, E., Towndrow, A. \& Aranguiz, A. (2013). Realising the Potential of Peer-toPeer Learning: Taming a MOOC with Social Media. J. eLearning Papers, 33.

Rekha, T., Williams, S. \& Adams, A. (2013). The Impact and Reach of MOOCs: A Developing Countries' Perspective. eLearning Papers, 33.

Romero, C. (2011). Handbook of educational data mining. Boca Raton, FL: CRC Press.

Romero, M. (2013). Game Based Learning MOOC. Promoting Entrepreneurship Education. J. eLearning Papers, 33.

Sánchez, E. \& Escribano, J. J. (2013). Posibles Mejoras en las plataformas MOOC para superar el "abismo de incertidumbre": Diseño web adaptativo y E-evaluación. SCOPEO INFORME, MOOC: Estado de la situación actual, posibilidades, retos y futuro, 2, 220237.

Sandeen, C. (2013). Assessment's Place in the New MOOC World. RPA, 8, Summer 2013, 5-12.

Sangrà, A., Guàrdia, L. \& Maina, M. (2013). MOOC Design Principles. A Pedagogical Approach from the Learner's Perspective. J. eLearning Papers, 33.

Siemens, G. (2012). What is the theory that underpins our moocs? Blog Elearnspace. Retrieved August 23, 2013 from http://www.elearnspace.org/blog/2012/06/03/what-isthe-theory-that-underpins-our-moocs/.

Siemens, G. \& Downes, S. (2008). Connectivism and Connective Knowledge Online Course.

Retrieved August 21, 2013 from http://www.elearnspace.org/connectivism.html.

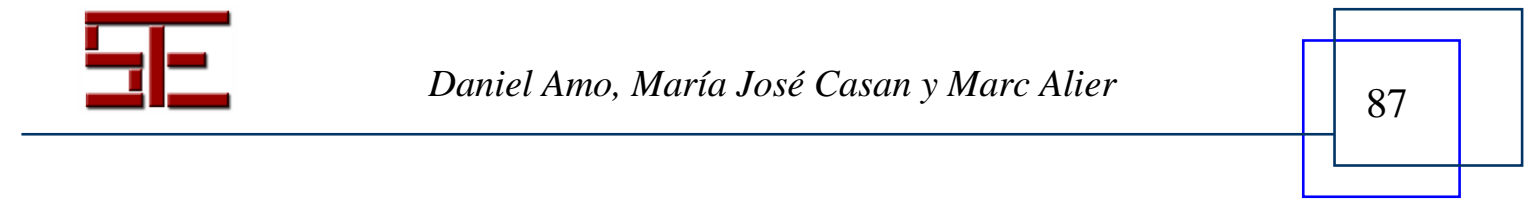




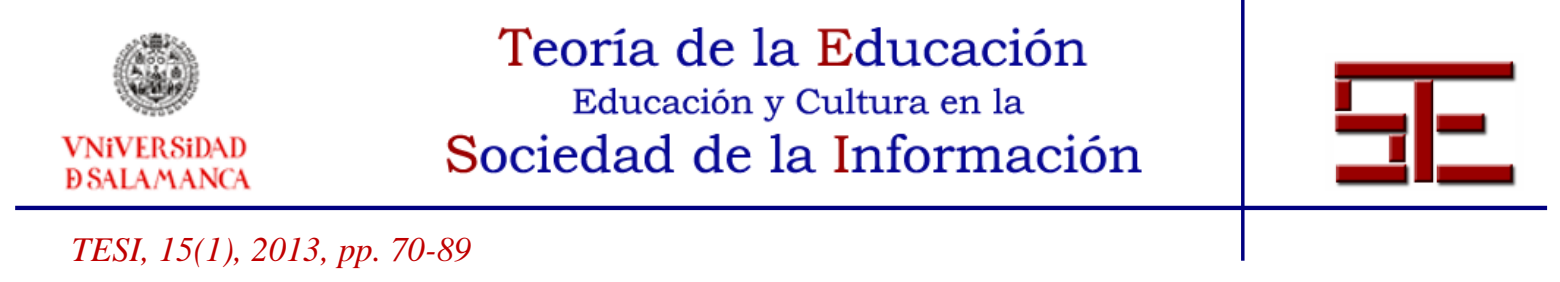

Siemens, G., Gasevic, D., Haythornthwaite, C., Dawson, S., Buckingham Shum, S., Ferguson, R., Duval, E., Verbert, K. \& Baker, R.S.J. (2011). Open Learning Analytics: an integrated \& modularized platform. Proposal to design, implement and evaluate an open platform to integrate heterogeneous learning analytics techniques. SOLAR Society for Learning Analytics Research.

Sonwalkar, N. (2013). The First Adaptive MOOC: A Case Study on Pedagogy Framework and Scalable Cloud Architecture-Part I. MOOCs FORUM, 1(P) (pp. 22-29).

Tabaa, Y. \& Medouri, A. (2013). LASyM: A Learning Analytics System for MOOCs. International Journal of Advanced Computer Science and Applications. vol. 4, 5.

Totschnig, M., Willems, C., Grünewald, F. \& Meinel, C. (2013). Designing MOOCs for the Support of Multiple Learning Styles. Proceedings of the 8th European Conference on Technology Enhanced Learning.

Towndrow, A., Aranguiz, A., Purser, E. \& Pradhan, M. (2013). Quad-blogging: Its Potential to Transform Peer-to-Peer Learning in a MOOC. J. eLearning Papers 33.

UNIMOOC-aemprende. (2013). Qué y Quiénes Somos. Retrieved August 21, 2013 from http://unimooc.com/landing/?page=quequienes.html.

Van Eck, R. (2006). Digital Game-Based Learning: It's Not Just the Digital Natives Who Are Restless. Retrieved August 23, 2013 from http://www.educause.edu/ero/article/digital-game-based-learning-its-not-just-digitalnatives-who-are-restless

Waard, I. I. (2013). MOOC YourSelf - Set up your own MOOC for Business, NonProfits, and Informal Communities. Inge Ignatia de Waard. United Kingdom, UK.

Watters, A. (2013). Hack Education Weekly News: A MOOC Master's Degree. Retrieved August 22, 2013 from http://www.hackeducation.com/2013/05/18/hackeducation-weekly-news-5-18-2013/.

Wikipedia (2013). Collective Intelligence. Retrieved August 23, 2013 from http://en.wikipedia.org/wiki/Collective_intelligence.

- (2013). Hype cycle. Retrieved August 23, 2013 from http://en.wikipedia.org/wiki/Hype_cycle.

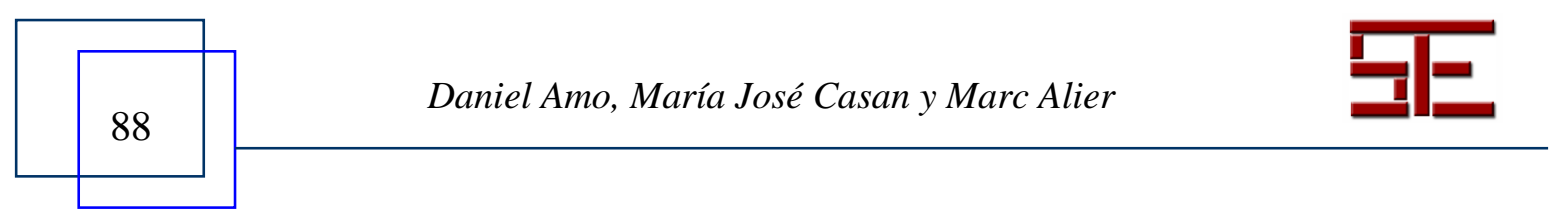




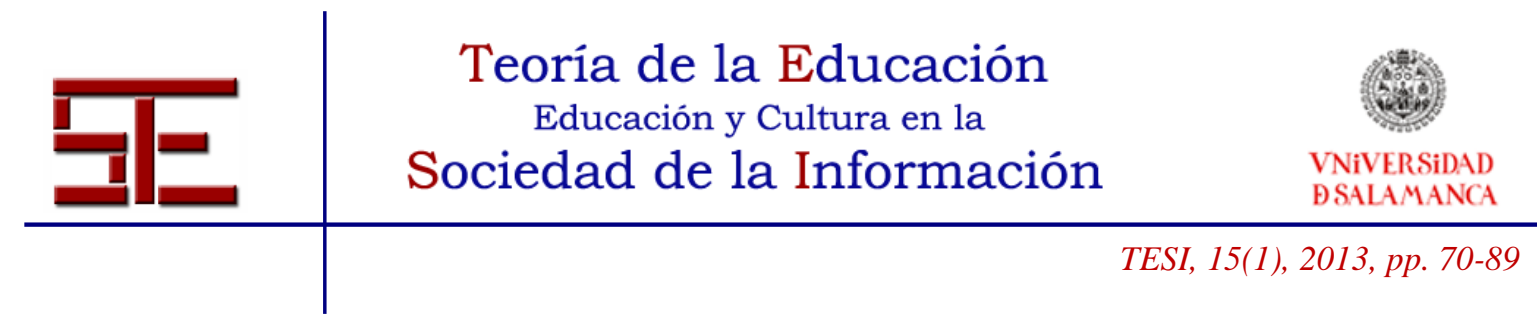

- (2013). Serious Games. Retrieved August 23, 2013 from http://en.wikipedia.org/wiki/Serious_game

Yang, D., Sinha, T., Adamson, D., \& Rose, C. P. (2013). "Turn on, Tune in, Drop out": Anticipating student dropouts in Massive Open Online Courses. Retrieved November 21, 2013 from http://lytics.stanford.edu/datadriveneducation/papers/yangetal.pdf.

Yuan, L. \& Powell, S. (2013). MOOCs and Open Education: Implications for Higher Education. Retrieved August 20, 2013 http://publications.cetis.ac.uk/2013/667.

Para citar el presente artículo puede utilizar la siguiente referencia:

Amo, D. Casany, M.J. y Alier, M. (2014). Approaches for quality in pedagogical and design fundamentals in moocs: Educación y Cultura en la Sociedad de la Información. 15(1), 70-89 [Fecha de consulta: dd/mm/aaaa].

http://campus.usal.es/ revistas_trabajo/index.php/revistatesi/article/view/11653/12068

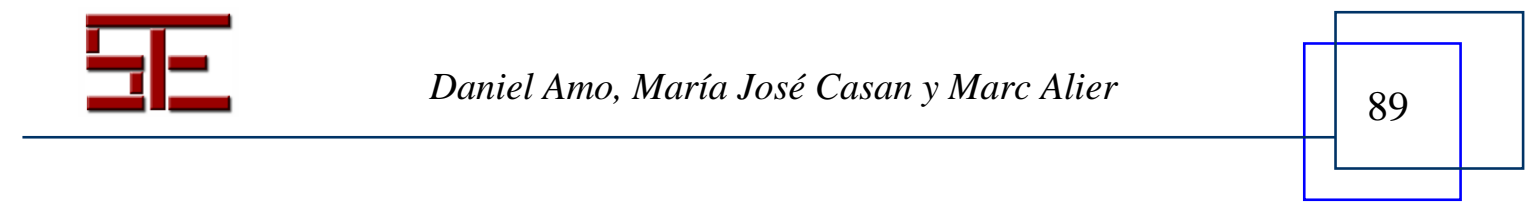

